\title{
Studies on Physicochemical and Functional Properties of Commercial Sweet Whey Powders
}

\author{
D. S. Banavara, D. Anupama, and S. A. Rankin \\ Department of Food Science, University of Wisconsin, Madison 53706
}

\section{ABSTRACT}

The objective of this study was to characterize variation and interrelatedness among primary functional and compositional parameters of commercially available sweet whey powders. Samples representing different plants/processes and cheese types were assayed for foaming capacity, foam stability, $\mathrm{pH}$, protein content, soluble protein, turbidity, color, particle size distribution, lipid, and moisture. Data were analyzed using principal component analysis. Foaming capacity and stability varied from 10 to $220 \%$ and 0.1 to $14 \mathrm{~min}$, respectively. Protein content and solubility ranged from 8.5 to $17.6 \%$ and 3.7 to $14.1 \%$, respectively. Lipid content of sweet whey powder varied from 0.03 to $2.00 \%$. The two main functional properties, foaming and protein solubility, did not show significant correlation with each other. Foaming properties showed a positive correlation to particle size and $\mathrm{L}^{*}$ or lightness value, and negative correlation to lipid content. Protein solubility showed positive correlation with protein content and negative correlation with turbidity of the sample. Foaming behavior, protein, and particle size attributes were the main variables responsible for grouping of samples. Sweet whey powders from the same dairy plants were grouped together. The direct or indirect significance of these relationships to processing is detailed in this study.

(Key words: sweet whey powder, physicochemical, functional properties)

Abbreviation key: D(0.5) = mean size of 50th-percentile particles in a given sample, $\mathbf{D E}^{*}=$ total color difference from standard white, $\mathbf{D}(\mathbf{m})=$ volume weighted mean size, $\mathbf{F}=$ lipid content, $\mathbf{F C}=$ foaming capacity, $\mathbf{F S}=$ foam stability, $\mathbf{M}=$ moisture, $\mathbf{P C}=$ protein content , PCA = principal component analysis, $\mathbf{P S}=$ particle size distribution, $\mathbf{S W P}=$ sweet whey powder, $\mathbf{S P C}=$ soluble protein content, $\mathbf{T}=$ turbidity, $\mathbf{W P C}=$ whey protein concentrate, $\mathbf{W P I}=$ whey protein isolate.

Received April 4, 2003.

Accepted August 20, 2003.

Corresponding author: S. A. Rankin; e-mail: sarankin@wisc.edu.

\section{INTRODUCTION}

Sweet whey powder (SWP) is a substantial byproduct of the cheese-manufacturing industry. Because of its numerous functional properties, such as browning, bulking, foaming, and water binding, SWP is utilized as an ingredient in a variety of food industries. For numerous reasons, the food industry has yet to fully recognize the potential of SWP as a food ingredient, such as whey protein concentrate (WPC) or whey protein isolate (WPI). In fact, a substantial amount of SWP is used as a component in animal feeds. Whey protein concentrate is also known to have limited application due to variable functionality and flavor (Morr, 1990; Morr and Ha, 1991). Harper and Lee (1997) evaluated 61 samples of a standard WPC from 6 US manufacturers, revealing significant differences in color, solubility, and functionality. There is a paucity of analogous assessments of SWP properties.

SWP is a complex mixture of lactose, proteins, minerals, with small amounts of moisture and fat. These constituents not only vary in quantity but also in physical state and association. The largest structural element of a SWP particle is lactose (amorphous or crystalline); fat is present in either globular or nonglobular (free fat) forms, and in air as spherical cells. Fat, protein, and air are dispersed in a continuous phase of amorphous lactose (Mulvihill and Grufferty, 1997). Sweet whey powder can be either hygroscopic or nonhygroscopic depending on processing conditions and the resulting physical state of lactose. As a food ingredient, the distinct physicochemical properties of SWP affect the quality of finished food product, most notably during storage and distribution (Saltmarch and Labuza, 1980). The lactose in SWP may exist in varying degrees of crystalline or amorphous forms. Sweet whey powder proteins may exist in denatured or native forms in either an unbound or lactose-encapsulated particulate state; moisture and lipid may exist in free and bound forms. The functional properties of SWP, such as solubility, water binding, foaming, and color, may vary depending on many constituents, such as lactose content and form, moisture content, protein content, protein solubility, bulk density, and particle size distribution. 
As a function of increased cheese production, the volume of SWP in the United States has increased substantially over the last few decades. Differences in variables such as milk quality, cheese type, whey handling practices, and whey processing equipment suggest that substantial quality and functional differences may exist in the pool of SWP available in the market. The objective of this study was to characterize the variation in commercial SWP in terms of functional and physicochemical variables and their interrelatedness. Thirtyfive SWP samples were procured from different manufacturers representing 5 different cheese types. The variation in functional and physicochemical properties of these powders was studied. Principal component analysis (PCA) was used to study the grouping of samples and to understand the relationships among variables.

\section{MATERIALS AND METHODS}

Reagents. All of the chemical reagents used for various assays in this study were of analytical grade (Fisher Scientific, Fair Lawn, NJ). The WPI was procured from Foremost Farms Inc. (Cochrane, WI).

Sweet whey powder. The SWP samples were procured from 6 dairy processing plants based in the upper Midwest region of the United States. Each sample that was received belonged to a different processing batch. Although the SWP samples were from distinct plants, it is a common practice to pool whey from different cheese types; thus, the actual cheese origin of the samples was confounded. The SWP samples in this study originated from proprietary blends of whey from 5 cheese types, including American style, Swiss, Mozzarella (pasta filata and nonpasta filata) and Cheddar.

\section{Various Assays}

Color. Instrumental measurement of SWP sample appearance was determined using a colorimeter (Colorquest 45/0, Hunterlab, Reston, VA). A SWP sample of approximately $10 \mathrm{~g}$ was placed in the sample cup. The CIE lab method was used to measure the parameters $L^{*}$ (lightness value), a* (green-red), b* (blue-yellow), DE* (total color difference relative to a standard white), $\mathrm{DC}^{*}$ (total chroma difference relative to a standard white), and WI (whiteness index). A standard ceramic white was used as blank. The illuminant was D65 at $10^{\circ}$ observer angle.

Protein content (PC). Protein content of whey powder samples was determined using Biuret assay (Morr et al., 1987) as modified by Richard and Paquin (1990). A protein solution (stock) was prepared using $0.15 \mathrm{~g}$ of WPI (manufacturer specification data: $94 \%$ protein content determined by Kjeldahl) in approximately 50 $\mathrm{ml}$ of deionized water. A solution of $0.05 \mathrm{~N} \mathrm{NaOH}$ was added, and the solution was made up to $100 \mathrm{ml}$ with deionized water to reach a final $\mathrm{pH}$ of 7.2. Appropriate aliquots of the dispersion $(0.05,0.1$, to $0.9 \mathrm{ml})$ were diluted to $1 \mathrm{ml}$ of solution to yield samples in the range of 70.5 to $1260 \mu \mathrm{g}$ of protein $/ \mathrm{ml}$. To each dilution, $4 \mathrm{ml}$ of biuret reagent was added and allowed to stand for 30 min. Absorbance of each solution was recorded at 540 nm using a spectrophotometer (Genesys 20, Spectronic, Inc., Rochester, NY). Each analysis was carried out in triplicate, and a standard curve was drawn for protein concentration vs. absorbance.

Sweet whey powder $(1 \mathrm{~g})$ was dissolved with 3 to 5 $\mathrm{ml}$ of $0.05 \mathrm{~N} \mathrm{NaOH}$ and the solution was made up to $100 \mathrm{ml}$ with deionized water. The final $\mathrm{pH}$ of the sample was adjusted to 7.2. This solution may contain protein in the range of 0.8 to $1.6 \mathrm{mg} / \mathrm{ml}$ (assuming SWP to have protein content in the range of 8 to 16\%). Four duplicate samples, each of $0.2,0.3,0.4$, and $0.5 \mathrm{ml}$ were made up to $1 \mathrm{ml}$ (the concentration falls in the range of 160 to $400 \mu \mathrm{g} / \mathrm{ml}$, at $8 \%$ protein content) and were mixed with $4 \mathrm{ml}$ of biuret reagent. This test sample was allowed to stand for $30 \mathrm{~min}$. Absorbance was recorded for each sample at $540 \mathrm{~nm}$. Protein content of whey powder was calculated using the standard curve of whey protein and expressed as the average of 8 values ( 4 samples in duplicate) obtained.

Soluble protein content (SPC). Analysis of protein solubility was carried out using the standardized procedure explained by Morr et al. (1987). However, instead of protein solubility (soluble:total protein ratio), soluble protein content (\%) with respect to dry weight of SWP was considered in this study. Two milliliters of $1 \% \mathrm{SWP}$ solutions were centrifuged for $45 \mathrm{~min}$ at $15,000 \times \mathrm{g}$ (at $22.5 \pm 1^{\circ} \mathrm{C}$ ) (Eppendorf 5804R, Hamburg, Germany). The supernatant liquid was drawn out as $0.2-, 0.4-$, and $0.8-\mathrm{ml}$ samples and made up to $1 \mathrm{ml}$ with deionized water. Biuret solution $(4 \mathrm{ml})$ was added to these samples and absorbance was recorded at $540 \mathrm{~nm}$ after allowing it to stand for $30 \mathrm{~min}$. The result of 6 readings (3 samples in duplicate) for each sample was averaged to express percentage of soluble protein content.

Foaming capacity (FC). Foaming capacity was measured using the procedure of Phillips et al. (1987) with slight modifications. The overall experimental approach was similar to that of Ven et al. (2002). The SWP dispersions in deionized water $(20 \% \mathrm{wt} / \mathrm{vol})$ were allowed to stand for about $5 \mathrm{~h}$ at room temperature to ensure dissolution of soluble constituents. Foaming capacity was studied using an overhead motor fixed with a three-blade propeller stirrer (Fisher Maxima Digital 70W, Fisher Scientific ). Exactly $200 \mathrm{ml}$ of sample was placed in a long, graduated beaker and whipped 
for 15 min. Foam volume was noted at 3-min intervals. The speed of the stirrer was fixed at $1300 \mathrm{rpm}$. The overrun was calculated as:

$$
\begin{gathered}
\text { Overrun, } \% \\
=\frac{(\text { Total volume at time }, \mathrm{t})-(\text { Initial volume })}{(\text { Initial volume }) \times 100} .
\end{gathered}
$$

Foam stability (FS). Several methods have been developed to accurately measure FS (Phillip et al., 1987; $\mathrm{Yu}$ and Damodaran, 1991). The time required for $50 \%$ of the total volume of foam formed to drain at room temperature was considered to be FS. Care was taken not to disturb the foam during draining and to maintain uniform temperature conditions throughout testing.

$\boldsymbol{p H}$. The SWP dispersions (20\% wt/vol) were allowed to stand for $5 \mathrm{~h}$ with intermittent shaking to ensure complete dissolution of soluble constituents and to hydrate proteins. The $\mathrm{pH}$ of these dispersions was measured using a standard $\mathrm{pH}$ measuring instrument (Accumet AB15, Fisher Scientific, Pittsburgh, PA).

Turbidity $(\boldsymbol{T})$. Turbidity has been used as a measure of protein-protein association and aggregation (Ju and Kilara, 1998), as well as lipid dispersion. Overall, $\mathrm{T}$ is a function of protein concentration and protein solubility. In practice, $0.5 \mathrm{ml}$ of a $1 \% \mathrm{SWP}$ solution was diluted with $9.5 \mathrm{ml}$ of deionized water. Percentage of transmittance was measured at $500 \mathrm{~nm}$. A transmittance of $100 \%$ was regarded as 0 turbidity and $0 \%$ as complete turbidity.

Particle size (PS). Particle size is known to affect the functionality and physicochemical properties of protein-rich powders (Kerr et al., 2000), including dairy products such as milk and whey powders (Neff and Morris, 1968). The PS was measured using a particlesizing device (Mastersizer 2000, Malvern, Inc., Southborough, MA). In this instrument, a particle obstructs a continuous laser beam directed onto a detector. Particle size is measured by the instrument using the principle of low-angle laser light scattering (laser diffraction) combined with Mie theory to solve the equations of light and object interaction. Approximately 5 to $8 \mathrm{~g}$ of SWP was placed in the sample holder. Pressure of 1.0 bar was applied to scatter the particles into the optical chamber while a continuous vacuum sucked the particles off the laser beam. Standard refractive index was fixed at 1.72 during the measurement. The duration of measurement was $10 \mathrm{~s}$. The parameters of volume-weighted means $\mathbf{D}(\mathbf{m})$ and median size of 50th-percentile particles $\mathbf{D}(\mathbf{0 . 5})$ were determined for further analysis.

Lipid $(\boldsymbol{F})$. Free F content in whey powder was determined using Soxhlet extraction (Russell et al., 1980). The SWP (20 g) was placed in single-use thimbles and was extracted for $20 \mathrm{~h}$ using a pentane:ether (60:40) solvent mixture. The $\mathrm{F}$ content of each sample was expressed as a percentage (wt/wt). Each analysis was carried out in duplicate.

Moisture (M). The moisture content of whey powders is influenced by processing and shipping and handling practices. The moisture content of SWP was determined in duplicate by a standard oven-drying method. Ruckold et al. (2000) outlines the difficulties and variations in determining true free moisture content of milk powder encountered with several methods. Knowing the variations in properties of SWP, care was taken to maintain the uniformity of measurement. Petri plates containing $1.5 \mathrm{~g}$ of SWP were placed in an oven at 103 $\pm 1^{\circ} \mathrm{C}$ for $4 \mathrm{~h}$ and weighed for constant final weight. After $2 \mathrm{~h}$ of drying, the samples were removed, carefully disturbed to expose particle surfaces and cooled for 15 to $20 \mathrm{~min}$ in a desiccator with activated silica gel. The samples were returned to the oven at $103 \pm 1^{\circ} \mathrm{C}$ for 1 $\mathrm{h}$. This process was repeated twice to obtain a final constant weight. It is believed that such a method reduces charring and optimally exposes free water while avoiding the evaporation of bound water present in lactose monohydrate (crystallized lactose) by continuous heat.

Principal component analysis (PCA). Principal component analysis extracts the dominant patterns in the data matrix in terms of a complimentary set of scores and loading plots (Cooley and Lohnes, 1971). Principal component analysis was used to group the samples based on selected variables to determine the importance of each variable. In this case, segregation of samples was done by considering each SWP sample to be a data vector of 12 variables represented by functional and physicochemical parameters. This technique estimates the correlation structure of the variables and denotes the relationship between the samples. Principal component analysis was carried out on 12 variables for 35 samples (JMP 4.0.4 software, SAS Inst., Inc., Cary, NC). Varimax factor rotation was used.

\section{RESULTS AND DISCUSSION}

\section{Principal Component Analysis}

The results of the various assays are shown in Table 1. Principal component (PC) analysis performed on 35 samples, and 12 variables yielded 3 important principal components with eigenvalues $>1$ (Kaiser criterion; Massart et al., 1988). The dimensionality of 12 variables was reduced to 3 uncorrelated components, with the first principal component (PC1) accounting for $46.08 \%$ of the variation, the second (PC2) for $19.52 \%$, and the third (PC3) for $10.04 \%$, making a total of $75.64 \%$ with the 3 components together. The Varimax rotation was performed on all 5 principal components, accounting 
SWEET WHEY POWDER PROPERTIES

Table 1. Results of various assays performed on sweet whey powder samples.

\begin{tabular}{|c|c|c|c|c|c|c|c|c|c|c|c|c|}
\hline Sample $^{1}$ & $\mathrm{~T}^{2}$ & $\mathrm{FC}, \%$ & $\mathrm{FS}, \min$ & $\mathrm{PC}, \%$ & SPC, \% & $\mathrm{F}, \%$ & $\mathrm{~L}^{* 2}$ & $\mathrm{~b}^{* 2}$ & $\mathrm{DE}^{* 2}$ & $\mathrm{D}(0.5), \mu \mathrm{m}$ & $\mathrm{D}(\mathrm{m}), \mu \mathrm{m}$ & $\mathrm{M}, \%$ \\
\hline $1^{\mathrm{e}}$ & 88.4 & 33 & 0.20 & 12.54 & 8.54 & 1.80 & 76.36 & 23.46 & 29.25 & 220.5 & 264.4 & 3.20 \\
\hline $2^{f}$ & 97.6 & 200 & 14.00 & 11.94 & 9.24 & 0.03 & 81.64 & 13.90 & 18.36 & 130.6 & 145.1 & 4.23 \\
\hline $3^{\mathrm{e}}$ & 88.6 & 46 & 0.25 & 10.95 & 7.38 & 0.09 & 78.25 & 22.54 & 27.25 & 205.9 & 229.3 & 2.31 \\
\hline $5^{\mathrm{b}}$ & 70.5 & 126 & 1.50 & 13.54 & 11.21 & 1.08 & 77.75 & 19.41 & 25.14 & 142.0 & 188.9 & 3.71 \\
\hline $6^{\mathrm{b}}$ & 78.8 & 186 & 3.50 & 12.54 & 11.02 & 0.80 & 78.59 & 18.77 & 24.02 & 99.6 & 121.1 & 3.50 \\
\hline $7^{\mathrm{a}}$ & 76.9 & 46 & 0.30 & 11.54 & 9.93 & 0.40 & 78.36 & 18.94 & 24.3 & 162.2 & 201.8 & 3.30 \\
\hline $8^{\mathrm{b}}$ & 67.7 & 60 & 0.75 & 15.48 & 14.01 & 0.15 & 79.26 & 16.52 & 21.87 & 131.9 & 174.9 & 2.75 \\
\hline $11^{\mathrm{f}}$ & 95.2 & 220 & 6.00 & 12.68 & 8.58 & 0.45 & 81.49 & 14.32 & 18.77 & 113.7 & 127.7 & 4.00 \\
\hline $12^{\mathrm{a}}$ & 79.0 & 46 & 0.30 & 17.64 & 14.12 & 0.11 & 78.07 & 18.25 & 23.98 & 170.5 & 246.6 & 3.75 \\
\hline $13^{\mathrm{f}}$ & 95.4 & 213 & 11.5 & 13.28 & 8.41 & 0.50 & 81.79 & 13.48 & 17.95 & 156.0 & 190.1 & 3.94 \\
\hline $14^{\mathrm{e}}$ & 91.9 & 140 & 2.50 & 13.33 & 9.12 & 0.16 & 78.45 & 21.84 & 26.56 & 166.4 & 187.7 & 2.21 \\
\hline $15^{\mathrm{f}}$ & 95.2 & 213 & 5.00 & 13.69 & 9.68 & 0.06 & 81.03 & 15.77 & 20.19 & 146.7 & 165.4 & 3.37 \\
\hline $16^{\mathrm{e}}$ & 93.8 & 60 & 0.30 & 11.94 & 8.14 & 0.64 & 77.95 & 21.53 & 26.65 & 170.5 & 199.5 & 2.43 \\
\hline $17^{\mathrm{a}}$ & 82.7 & 40 & 0.30 & 9.84 & 9.77 & 0.30 & 78.42 & 18.97 & 24.29 & 162.4 & 221.5 & 3.48 \\
\hline $22^{\mathrm{d}}$ & 94.7 & 200 & 2.00 & 11.92 & 7.62 & 0.12 & 80.48 & 14.17 & 19.36 & 92.8 & 102.6 & 3.59 \\
\hline $23^{\mathrm{f}}$ & 95.5 & 170 & 1.20 & 11.69 & 10.73 & 0.10 & 81.01 & 15.83 & 20.25 & 124.0 & 117.5 & 3.40 \\
\hline $24^{\mathrm{f}}$ & 97.4 & 180 & 3.25 & 11.10 & 10.16 & 0.14 & 81.24 & 14.67 & 19.21 & 186.3 & 221.9 & 3.41 \\
\hline $25^{\mathrm{a}}$ & 87.9 & 40 & 0.50 & 11.15 & 12.40 & 0.05 & 78.23 & 19.78 & 25.06 & 136.0 & 176.1 & 2.98 \\
\hline $26^{\mathrm{a}}$ & 79.6 & 40 & 0.50 & 12.62 & 11.93 & 0.04 & 78.87 & 17.68 & 23.01 & 180.2 & 243.3 & 3.17 \\
\hline $27^{\mathrm{b}}$ & 79.6 & 175 & 2.10 & 13.37 & 10.64 & 0.30 & 78.96 & 17.86 & 23.09 & 150.5 & 164.7 & 3.22 \\
\hline $28^{\mathrm{a}}$ & 90.3 & 10 & 0.10 & 12.34 & 7.59 & 0.40 & 78.34 & 19.73 & 24.94 & 131.6 & 160.7 & 2.99 \\
\hline $29^{\mathrm{a}}$ & 84.4 & 30 & 0.20 & 13.05 & 11.90 & 1.25 & 79.04 & 18.84 & 23.79 & 159.8 & 212.4 & 2.54 \\
\hline $30^{\mathrm{b}}$ & 79.6 & 165 & 1.70 & 12.89 & 11.35 & 0.15 & 78.30 & 18.34 & 23.89 & 137.9 & 159.2 & 3.10 \\
\hline $31^{\mathrm{f}}$ & 96.9 & 170 & 1.50 & 10.98 & 9.67 & 0.23 & 79.45 & 15.11 & 19.36 & 169.3 & 203.2 & 3.19 \\
\hline $32^{\mathrm{c}}$ & 91.2 & 45 & 0.65 & 11.37 & 7.89 & 0.84 & 79.94 & 13.69 & 19.51 & 169.1 & 171.2 & 2.55 \\
\hline $33^{c}$ & 96.7 & 50 & 0.50 & 11.12 & 10.00 & 1.65 & 78.84 & 18.52 & 23.72 & 159.9 & 185.9 & 2.73 \\
\hline $34^{\mathrm{c}}$ & 90.9 & 50 & 0.65 & 10.79 & 7.94 & 0.81 & 79.81 & 14.62 & 20.25 & 164.1 & 178.4 & 2.79 \\
\hline $35^{\mathrm{d}}$ & 98.4 & 200 & 3.50 & 13.73 & 6.43 & 0.12 & 80.55 & 13.71 & 18.98 & 79.9 & 104.2 & 3.44 \\
\hline
\end{tabular}

${ }^{1}$ Samples with same lower-case letters originate from same dairy plant.

${ }^{2} \mathrm{D}(0.5)=$ mean size of 50th-percentile particles in a given sample, $\mathrm{D}(\mathrm{m})=$ volume weighted mean size, $\mathrm{F}=$ lipid content, $\mathrm{FC}=$ foaming capacity, $\mathrm{FS}=$ foam stability, $\mathrm{M}=$ moisture, $\mathrm{DE}=$ total color difference from standard white, $\mathrm{PC}=$ protein concentrate, $\mathrm{SPC}=$ soluble protein content, $\mathrm{T}=$ turbidity.

for $88.39 \%$ of the variance. This rotation brings the newly generated variables (principal components) into closer alignment with the original variables. The Varimax factor loadings, which represent correlation between principal component and the measured variable, are shown in Table 2. Factor loadings, with absolute values greater than 0.70 , represented a strong influence and are shown in bold letters in Table 2.

Protein content 1 is highly related to foaming variables FS and FC. Similarly, PC2 showed a higher relation with protein variables SPC, PC, and T. Principal component 3 was largely related to particle size attributes $\mathrm{D}(0.5)$ and $\mathrm{D}(\mathrm{m})$. Principal components 4 and 5 showed a high relation to $\mathrm{F}$ and color attributes ( $\mathrm{L}^{*}$, $\mathrm{b}^{*}$ and $\mathrm{DE}^{*}$ ), respectively. Figures 1 and 2 represent the measured variables as a function of principal components in two-dimensional spaces PC1:PC2 (46.08:19.52) and PC1:PC3 (46.08:10.04), respectively.
These figures show grouping of samples from different manufacturers (labeled as a, b, c, d, e, and f) in the multidimensional space based on their proximity to the vectors (higher scores for the variables). Figure 1 clearly shows samples from the same manufacturer in closer groups, indicating that product variations are caused, in fact, by individual processing plants. Most of the samples from manufacturer $f$ had higher values for FS, FC, moisture, and $\mathrm{L}^{*}$, whereas most of the samples from a, e, and c had higher scores for $\mathrm{D}(\mathrm{m}), \mathrm{DE}^{*}, \mathrm{D}(0.5)$, and $b^{*}$. Samples from $b$ were found to be similar to the variables protein content and SPC, and samples from d were found close to the variable turbidity. Due to the industrial practice of blending whey from different cheese types, it was difficult to determine the exact cheese type of SWP. Hence, the relationship between cheese type and grouping of samples could not be established authentically. Figure 3 shows the vectors (vari- 
Table 2. Factor loadings for principal components (rotated). ${ }^{1}$

\begin{tabular}{|c|c|c|c|c|c|}
\hline Variable $^{2}$ & Factor 1 & Factor 2 & Factor 3 & Factor 4 & Factor 5 \\
\hline $\mathrm{T}$ & -0.192 & 0.804 & -0.012 & -0.198 & -0.321 \\
\hline $\mathrm{FC}$ & -0.733 & 0.026 & -0.399 & 0.228 & -0.291 \\
\hline FS & -0.863 & 0.088 & -0.077 & -0.014 & -0.310 \\
\hline $\mathrm{PC}$ & -0.216 & -0.859 & -0.081 & -0.071 & -0.022 \\
\hline SPC & 0.084 & -0.909 & 0.104 & 0.008 & 0.001 \\
\hline $\mathrm{F}$ & 0.179 & 0.059 & 0.097 & -0.940 & 0.179 \\
\hline $\mathrm{L}^{*}$ & -0.441 & 0.263 & -0.193 & 0.104 & -0.789 \\
\hline$b^{*}$ & 0.292 & -0.011 & 0.282 & -0.121 & 0.887 \\
\hline $\mathrm{DE}^{*}$ & 0.339 & -0.080 & 0.255 & -0.130 & 0.887 \\
\hline $\mathrm{D}(0.5)$ & 0.177 & 0.079 & 0.927 & -0.103 & 0.224 \\
\hline $\mathrm{D}(\mathrm{m})$ & 0.179 & -0.116 & 0.926 & -0.025 & 0.249 \\
\hline $\mathrm{M}$ & -0.684 & -0.128 & -0.163 & 0.194 & -0.357 \\
\hline
\end{tabular}

${ }^{1}$ Factors in bold indicate the variables that load the factors maximally.

${ }^{2}$ See Table 1 for abbreviation definitions.

ables) and their grouping in the multidimensional space. Foam stability, FC, and moisture formed a group, and $\mathrm{b}^{*}$ and $\mathrm{DE}^{*}$ formed another group. The samples were grouped mainly based on foaming behavior (FS and $\mathrm{FC}$ ), protein (SPC, PC, and T), and particle size distribution $(\mathrm{D}[0.5]$ and $\mathrm{D}[\mathrm{m}])$. However, the significance of lipid content and color parameters $\left(\mathrm{L}^{*}, \mathrm{~b}^{*}\right.$, and $\left.\mathrm{DE}^{*}\right)$ in distinguishing SWP samples cannot be overlooked. The $\mathrm{pH}$ of all SWP dispersions varied from
5.95 to 6.05 . This narrow range was not found to be a significant contributor to variations in sample performance.

Multivariate correlations. The matrix of correlation coefficients that summarizes the strength of linear relationships between each pair of measured variables is shown in Table 3. A Pearson's r value (+ve or -ve) of 0.33 or higher was found to be significant $(P \leq 0.05)$ for a sample size of 35 .

\section{PC1:PC2}

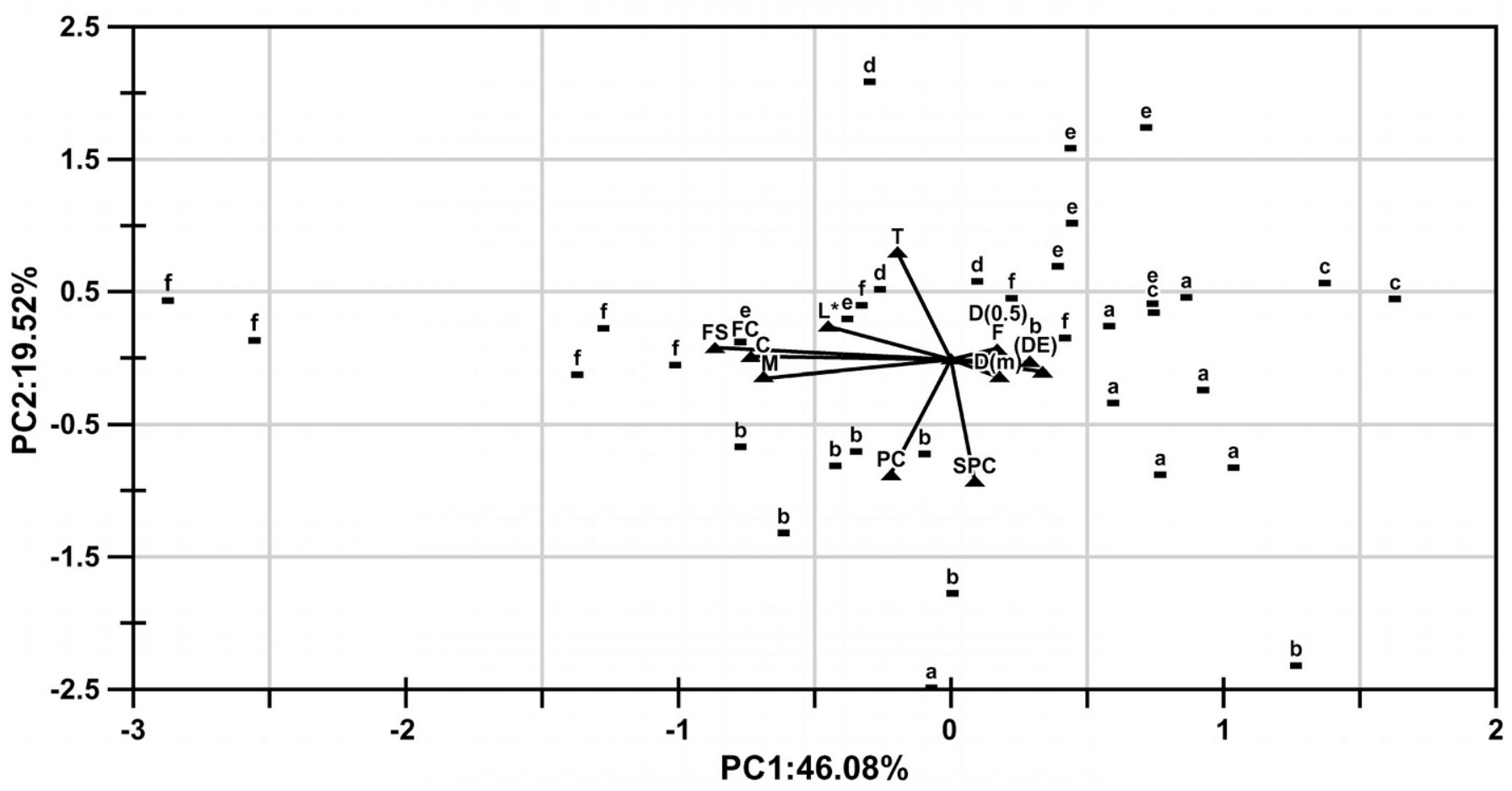

Figure 1. Principal component analysis of sweet whey powder samples. PC1: PC2, samples $(\boldsymbol{\square})$ and variables $(\boldsymbol{\Delta})$. $\mathrm{D}(0.5)=\mathrm{mean}$ size of 50th-percentile particles in a given sample, $\mathrm{D}(\mathrm{m})=$ volume weighted mean size, $\mathrm{FC}=$ foaming capacity, $\mathrm{FS}=$ foam stability, $\mathrm{M}=$ moisture, $\mathrm{DE}=$ total color difference from standard white, $\mathrm{PC}=$ protein concentrate, $\mathrm{SPC}=$ soluble protein content, $\mathrm{T}=$ turbidity. 


\section{PC1:PC3}

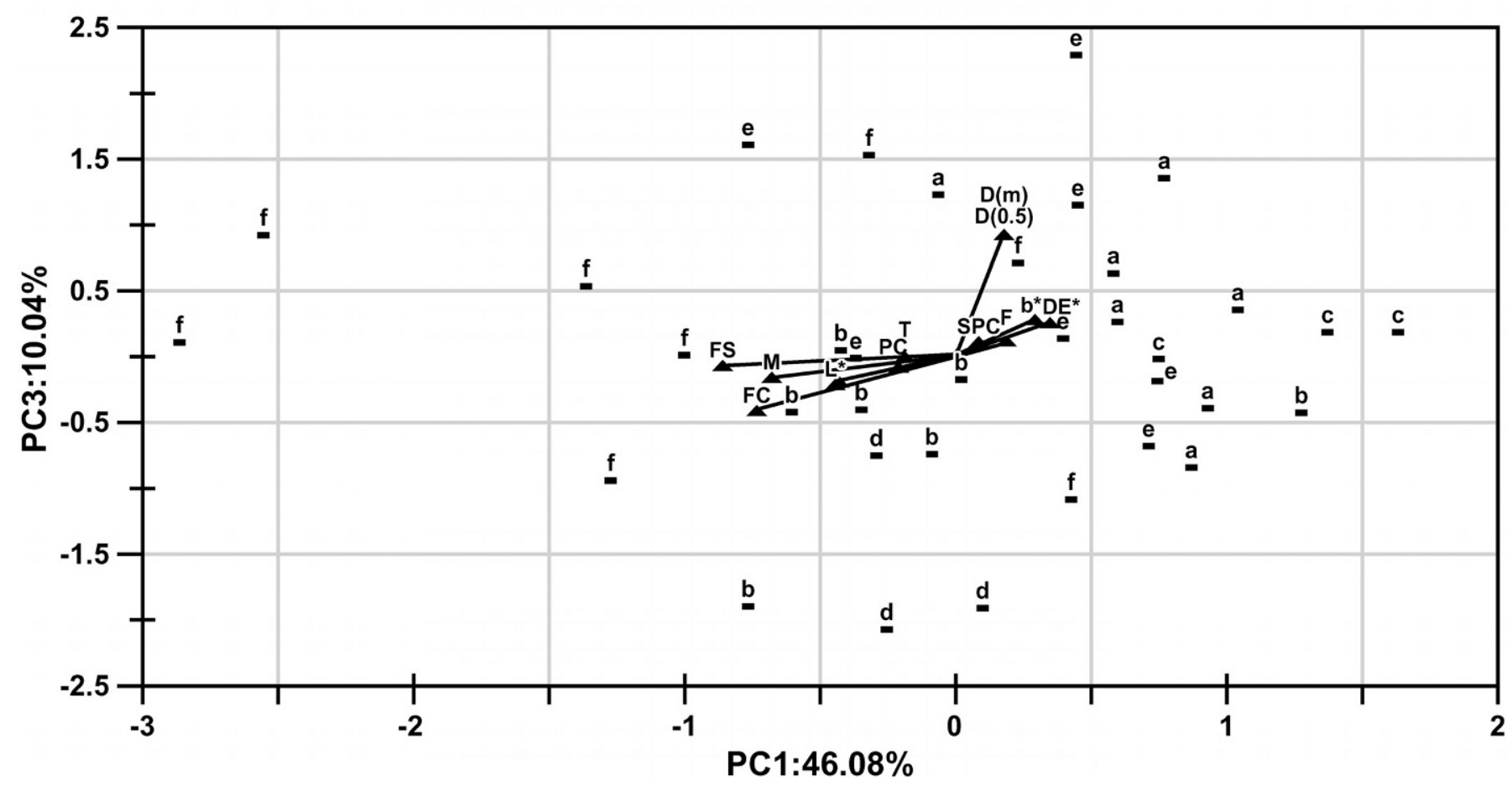

Figure 2. Principal component analysis of sweet whey powder samples. PC1: PC3, samples (匚) and variables (ム). See Figure 1 for abbreviation definitions.

\section{Physicochemical Properties}

Color. Instrumental analysis of color of dry samples showed a large variation in lightness value $L^{*}(76.36$ to 81.64$)$. The $\mathrm{DE}^{*}$ also varied largely, with the values ranging from 17.95 to 29.25 . The $\mathrm{b}^{*}$ value, a measure of yellowness, varied from 13.48 to 22.54 . The $\mathrm{L}^{*}, \mathrm{DE}^{*}$, and $b^{*}$ values were considered to be important variables and were included for PCA. The red component, $a^{*}$, was not considered significant due to prominent yellowness in SWP. The $\mathrm{L}^{*}$ had a negative correlation with estimates of particle size parameters, $\mathrm{D}(0.5)(\mathrm{r}=-0.41)$ and $\mathrm{D}(\mathrm{m})(\mathrm{r}=-0.51)$. An increase in $\mathrm{L}^{*}$ values with a decrease in particle size has been observed by other researchers for red pepper powders (Chen et al., 1999) and pigment powders (Jevenkoski et al., 1995). A powder with smaller particles and less construed morphology packs more closely, exhibits more surface over a given exposed area, and thus reflects more light. Yellowness ( $b^{*}$ ) of SWP may arise from the contributions of several pigments, including endogenous carotenoids, bixin residuals, or Maillard browning products.

Particle size. Particle size distribution in whey powders ranged from 10 to $1200 \mu \mathrm{m}$. The $\mathrm{D}(\mathrm{m})$ and $\mathrm{D}(0.5)$ varied from approximately 100 to 275 and 75 to 240 $\mu \mathrm{m}$, respectively. This vast difference in size can be attributed to processing conditions employed at the plant. Dairy plants employ several methods of water removal, such as multiple-effect and falling film evaporation, followed by spray drying. Typically, filtermattype dryers or fluidized bed dryers are employed to control the residual moisture content in the final product. A few smaller plants try to achieve complete drying in the spray dryer itself by reducing nozzle pressure (lower feed rates) and increasing inlet air temperature. Additionally, whey may be atomized either by a stationary high-pressure nozzle or a rotary disk atomizer. Hence, the particle size variations might be a result of processing method and equipment design. In liquid whey, lactose crystals are solid particles suspended in an aqueous dispersion of protein, soluble lactose, lipid, minerals, and other minor constituents. During the spray-drying process, fine whey particles are created during the atomization process. Water is initially lost from the exterior of these particles, creating a lactoseprotein matrix on the outer surface and a relatively hollow particle core. The PS is also influenced by viscosity (Marshall, 1954), which in turn is affected by lactose crystallization and protein solubility. The PS attributes showed positive correlation with fat content (Table 3). During drying, the fat may become entrapped in the 


\section{PC1:PC2}

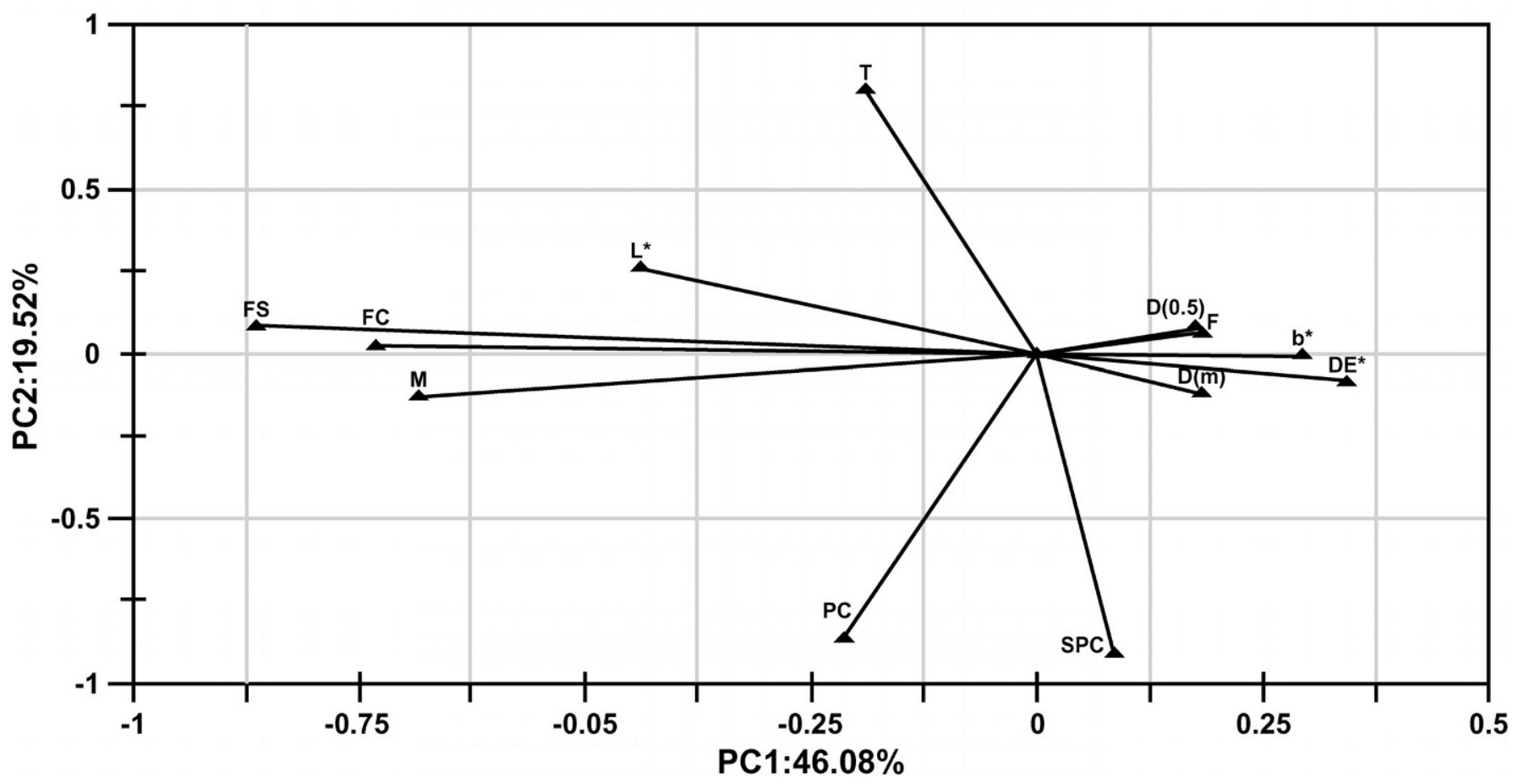

Figure 3. Vector positions in multidimensional space. PC1: PC2 variables $(\boldsymbol{\Delta})$. See Figure 1 for abbreviation definitions.

protein-lactose complex or remain as free fat. Due to increased surface adhesion, the presence of entrapped or free fat may result in particle agglomeration and hindered comminution after drying, thus increasing the particle size.

Lipid. Lipid content of SWP varied from 0.03 to $2.0 \%$. For economic reasons as well as for flavor stability, whey cream is typically recovered from the liquid whey stream (Mulvihill and Grufferty, 1997). The US grading standards for SWP state a maximal milkfat content of $1.5 \%$ (USDA, 2000). Fat content of whey varies de- pending on process parameters such as the strength of the coagulum at cutting, the curd-cutting mechanism (manual vs. mechanical), the size of the curd, and time allowed for skin formation on curd particles (Johnson et al., 2001). Several methods have been adopted to remove the residual milk fat from whey (Pearce, 1992). Although whey contains only a small amount of lipid, volatile lipid oxidation products were reported to be the main contributors to off flavors, both in liquid and dried whey (Swaisgood, 1996). Presence of milk fat may affect ease of flow, particle size, and color, while also being a

Table 3. Correlation coefficients between physicochemical and functional variables of sweet whey powder. ${ }^{1}$

\begin{tabular}{|c|c|c|c|c|c|c|c|c|c|c|c|c|}
\hline Variable & $\mathrm{T}$ & FC & FS & $\mathrm{PC}$ & SPC & $\mathrm{F}$ & $\mathrm{L}^{*}$ & $\mathrm{~b}^{*}$ & $\mathrm{DE}^{*}$ & $\mathrm{D}(0.5)$ & $\mathrm{D}(\mathrm{m})$ & M \\
\hline $\mathrm{T}$ & 1.00 & & & & & & & & & & & \\
\hline $\mathrm{FC}$ & 0.23 & 1.00 & & & & & & & & & & \\
\hline FS & 0.32 & 0.68 & 1.00 & & & & & & & & & \\
\hline PC & -0.52 & 0.16 & 0.11 & 1.00 & & & & & & & & \\
\hline SPC & -0.69 & -0.10 & -0.13 & 0.67 & 1.00 & & & & & & & \\
\hline $\mathrm{F}$ & 0.08 & -0.42 & -0.24 & -0.10 & -0.05 & 1.00 & & & & & & \\
\hline $\mathrm{L}^{*}$ & 0.55 & 0.67 & 0.69 & -0.09 & -0.26 & -0.34 & 1.00 & & & & & \\
\hline$b^{*}$ & -0.28 & -0.61 & -0.54 & -0.08 & 0.11 & 0.33 & -0.86 & 1.00 & & & & \\
\hline $\mathrm{DE}^{*}$ & -0.37 & -0.65 & -0.59 & -0.03 & 0.14 & 0.35 & -0.92 & 0.99 & 1.00 & & & \\
\hline $\mathrm{D}(0.5)$ & -0.03 & -0.53 & -0.30 & -0.16 & 0.04 & 0.26 & -0.41 & 0.52 & 0.50 & 1.00 & & \\
\hline $\mathrm{D}(\mathrm{m})$ & -0.23 & -0.58 & -0.34 & -0.02 & 0.19 & 0.20 & -0.51 & 0.52 & 0.52 & 0.91 & 1.00 & \\
\hline M & 0.05 & 0.64 & 0.58 & 0.16 & 0.00 & -0.32 & 0.53 & -0.62 & -0.61 & -0.44 & -0.30 & 1.00 \\
\hline
\end{tabular}

${ }^{1}$ See Table 1 for abbreviation definitions. 
cause of stickiness during drying as seen in case of milk powders (Woodhams and Murray, 1974). There was a negative correlation of fat to $L^{*}(r=-0.34)$ and a positive correlation to $b^{*}(r=0.33)$. This suggests that an increase in milk fat content of whey powder imparts yellowness while reducing the brightness of the sample. In a recent study by Koc et al. (2003), white milk powder turned into a yellow paste when the free fat content was increased. The increase in yellow hue can be attributed to an increased concentration and exposure of pigments present in the milk fat.

\section{Functional Properties}

Protein content and solubility. United States Department of Agriculture grading standards require a minimal SWP protein content of $11 \%$ (USDA, 2000). In this study, protein content varied from 8.5 to $14 \%$, with an average of $12.2 \%$. Protein content is one of the important parameters responsible for the functionality and nutritional value of whey products. Surprisingly, protein content did not have a significant correlation with FC $(\mathrm{r}=0.16)$ or FS $(\mathrm{r}=0.11)$. Protein solubility (SPC) varied between 4.5 and $12.0 \%$. The correlation between protein content and SPC was positive $(r=0.67)$. However, several samples with a high protein content exhibited low protein solubility. Variations in protein content and SPC can be attributed to several processing parameters. Sweet whey powder manufacturing can involve various processes, including numerous heat treatments (multiple pasteurizations, hot well holding, evaporation, spray dryer chamber), increases in osmotic strength during concentration, $\mathrm{pH}$ changes, and contributions from different cheese cultures and manufacturing procedures. Although care is taken not to denature the protein during these unit operations, the fate of proteins and the overall effect of processing on protein content and SPC are not clearly understood. Variations in whey protein content and solubility in WPC have also been observed by other researchers (de Wit et al., 1986). Surprisingly, Table 3 does not show any significant correlation of protein content and SPC with other physicochemical or functional properties, except with turbidity.

Turbidity. The turbidity test is used as a routine method for determining the degree of protein solubility in aqueous dispersions. The $\mathrm{T}$ of protein dispersions is generally attributed to insoluble, denatured protein and protein aggregates. In this study, the strongly negative correlation of $\mathrm{T}$ with $\mathrm{SPC}(\mathrm{r}=-0.69)$ demonstrates that increases in SPC result in decreased turbidity values, as expected. In SWP, high T values are thought to result from extended heat, acid, and storage treatments where denatured proteins and resulting colloidal pro- tein aggregates are of sufficient diameter to refract light. This hypothesis is further supported by a strong correlation between $\mathrm{T}$ and $\mathrm{L}^{*}(\mathrm{r}=0.55)$, where $\mathrm{L}^{*}$ of solutions are considered to be a function of the concentration and size of suspended particles (Rankin and Brewer, 1998).

Foaming behavior. Foaming capacity is a valuable functional property for SWP because of its application in certain foods as a foaming aid. Foaming capacity varied between 10 and $220 \%$. There was variation in FC, FS, and rate of overrun development (data not shown for overrun development). Foaming stability (50\% drain) also varied from 0.1 to $14 \mathrm{~min}$. Foam formation is due to many factors, including the inherent character of protein molecules (e.g., presence of sulfhydryl groups) that unfold at the air-water interface. The foaming properties of different proteins vary largely due to wide variations in properties at the molecular level, as well as the state of denaturation. The active role of such molecular properties in foam formation and stability is well documented by Phillip et al. (1994a). Hence, FC and FS in SWP depends on the concentration and state of protein. However, in this study there was no significant correlation of SPC with FC $(\mathrm{r}=-0.10)$ and FS $(r=-0.13)$. Similar observations have also been observed with WPC by other researchers (Mangino et al., 1987). The solution viscosity contributed by soluble peptides/proteins and sugars plays an important role in the formation and stability of films (Kinsella and Phillips 1989). Whey protein concentrate and SWP possess high lactose contents in soluble and insoluble forms. The amount of soluble lactose alters the viscosity of the aqueous phase, which in turn may influence the foam stability. Additionally, the foaming character of SWP proteins depends on a complex balance between many intrinsic factors, such as surface hydrophobicity, charge frequency, and noncovalent interactions (Damodaran 1996). Factors such as the ratio of soluble and insoluble proteins and the number and accessibility of free sulfhydryl groups of $\beta$-lactoglobulin can vary substantially with processing. Hence, a weak relationship between protein content, SPC, and foaming is not unusual in complex systems such as SWP. Table 3 reveals a negative correlation of $\mathrm{FC}$ with $\mathrm{F}(\mathrm{r}=-0.42), \mathrm{b}^{*}(\mathrm{r}=$ $-0.61), \mathrm{DE}^{*}(\mathrm{r}=-0.65)$, and PS attributes. The negative influence of lipid content on foaming character of whey proteins has been recognized by other researchers (Karleskind et al., 1995). Lipids are known to destabilize foams by displacing proteins from the air/water interface. However, the correlation coefficient $(r=$ -0.42 ) suggests that $\mathrm{F}$ is not the sole factor in determining the FC in SWP. Foaming capacity had a negative correlation with particle size attributes $(\mathrm{r}=-0.58$ and -0.53 , respectively, for $\mathrm{D}[\mathrm{m}]$ and $\mathrm{D}[0.5]$ ), indicating the 
importance of small particle size for increased FC. Foaming stability showed a trend similar to particle size attributes. During foam formation, proteins should be able to unfold readily and to form a film at the airwater interface. The ability of proteins to unfold depends on many factors, including the access of proteins to the air-water interface. In complex mixtures such as SWP, lactose may encapsulate or adhere to the active sites of protein. In such cases, the reduced solubility of amorphous lactose inhibits protein hydration, thus film formation is hindered at the air-water interface. Drying the whey into finer particles decreases such a hindrance by increasing the surface area and easy access of proteins to the air-water interface. A positive correlation of FC with $\mathrm{L}^{*}(\mathrm{r}=0.67)$ may in turn be a result of smaller particle size and lower $\mathrm{F}$.

It can be inferred that optimized conditions for drying and comminution of SWP are capable of influencing the appearance ( $\mathrm{L}^{*}$ value) and FC. Interestingly, moisture, recognized as potentiating certain SWP defects such as off-flavor development and agglomeration, showed a positive correlation with $\mathrm{FC}(\mathrm{r}=0.64)$. A partial understanding of this correlation may reside with the initial degree of hydration in SWP particles. Spray-dried SWP can be characterized as having 2 main particle types: solid lactose crystal particles and lactose-encapsulated hollow particles formed during evaporation of water from the remaining liquid during atomization (Marshall, 1954). Lactose and whey proteins associate with water in several complex ways that greatly influence their structure and functional properties (Phillip et al., 1994b). It can be hypothesized that increased moisture creates a condition where the lactose and proteins exist in a higher state of initial hydration and are thus more readily solved into water in the $\mathrm{FC}$ assay.

Foaming stability showed a positive correlation to FC $(\mathrm{r}=0.68)$. A few high-foaming samples had low FS, suggesting that additional factors influence the complex variations and inherent molecular properties of proteins in foaming (Phillip et al., 1994a).

The grouping of samples based on dairy plant showed that the samples from the same plant had similar foaming behavior (Figure 1). Although cheese type may still have an effect on SWP, this outcome underscores the role of processing method and protocol on the functional properties of SWP.

\section{CONCLUSIONS}

In a complex food product such as SWP, it is important to understand both the individual and collective effects of the variables that define it. Principal component analysis showed that SWP samples were grouped mainly by the following variables: foaming behavior, protein, and particle size attributes. The 2 main functional properties, foaming and protein solubility, were not well correlated. However, their relations to other physicochemical parameters, such as particle size, color, lipid, and moisture, were found to be of significance. This survey of commercially available SWP samples suggests the need to conduct controlled studies detailing the single and combined effects of SWP manufacturing and compositional variables.

\section{ACKNOWLEDGMENTS}

The authors wish to express their appreciation to the Wisconsin Milk Marketing Board, Inc., for providing financial assistance. Funding has also been provided for this research and publication from the USDA Cooperative State Research, Education and Extension Service (CSREES) project WIS04596.

\section{REFERENCES}

Chen, Q., H. K. Koh, and J. B. Park. 1999. Color evaluation of red pepper powder. Trans. ASAE. 42(3):749-752.

Cooley, W. W., and P. R. Lohnes. 1971. Multivariate Data Analysis. John Wiley \& Sons, New York, NY.

Damodaran, S. 1996. Functional properties. Pages 167-234 in Food Proteins: Properties and Characterization. S. Nakai and H. W. Modler. ed. VCH Publishers, New York, NY.

de Wit, J. N., G. Klarenbeek and M. Adamse. 1986. Evaluation of functional properties of whey protein concentrates and whey protein isolates. 2. Effects of processing history and composition. Neth. Milk Dairy J. 40:41-56.

Harper, W. J., and K. M. Lee. 1997. Functional properties of $34 \%$ whey protein concentrates. Pages 140-153 in Whey: Proc. of the 2nd Int. Whey Conf., Chicago, IL.

Javenkoski, J. S., S. J. Schmidt, M. D. B. Jimenez, and B. O. Carragher. 1995. A physical basis for understanding the color strength of fruit and vegetable powders. Page 65 Proc. of the IFT Annu. Mtg. IFT, Chicago, IL.

Johnson, M. E., C. M. Chen, and J. J. Jaeggi. 2001. Effect of rennet coagulation time on composition, yield, and quality of reducedfat Cheddar cheese. J. Dairy Sci. 84:1027-1033.

Ju, Z. Y., and A. Kilara. 1998. Aggregation induced by calcium chloride and subsequent thermal gelation of whey protein isolate. J. Dairy Sci. 81:925-931.

Karleskind, D., I. Laye, F. I. Mei, and C. V. Morr. 1995. Foaming properties of lipid-reduced and calcium-reduced whey protein concentrates. J. Food Sci. 60:738-741.

Kerr, W. L., C. D. W. Ward, K. H. McWatters, and A. V. A. Resurreccion. 2000. Effect of milling and particle size on functionality and physicochemical properties of cowpea flour. Cereal Chem. 77:213-219.

Kinsella, J. E., and L. G. Phillips. 1989. Structure:function relationships in food proteins: Films, and foaming behavior. Pages 5277 in Food Proteins. J. E. Kinsella and W. G. Soucie, ed. Am. Oil Chem. Soc., Champaign, IL.

Koc, A. B., P. H. Heinemann, and G. R. Ziegler. 2003. A process for increasing the free fat content of spray dried whole milk powder. J. Food Sci. 68:210-216.

Massart, D. L, B. G. M. Vandeginste, S. N. Deming, Y. Michotte, and L. Kaufman. 1988. Principal component and factor analysis. Pages 339-369 in Chemometrics: A Textbook. Elsevier, Amsterdam, The Netherlands.

Mangino, M. E., J. H. Kim, J. A. Dunkerley and J. G. Zadow. 1987. Factors important for the gelation of whey protein concentrates. Food Hydrocolloids 1:277-282. 
Marshall, W. R., 1954. Some general design and performance considerations. Pages 105-116 in Atomisation and Spray Drying. Johensen Crosby and Assoc., Madison, WI.

Morr, C. V. 1990. Whey protein functionality: current status and the need for improved quality and functionality. Page 69 in Proc. of the Dairy Prod. Technical Conf., Chicago, IL.

Morr, C. V., and E. Y. W. Ha. 1991. Off-flavors of whey protein concentrates: A literature review. Int. Dairy J. 1:1-11.

Morr, C. V., J. B. German, J. E. Kinsella, J. M. Regenstein, J. P. van Buren, A. Kilara, B. A. Lewis, and M. E. Mangino. 1987. A collaborative study to develop a standardized food protein solubility procedure. J. Food Sci. 50:1715-1718.

Mulvihill, D. M., and M. B. Grufferty. 1997. Production of wheyprotein-enriched products. Pages 77-93 in Food Proteins and Lipids. S. Damodaran, ed. Plenum Press, New York, NY.

Neff, E., and H. A. L. Morris. 1968. Agglomeration of milk powder and its influence on reconstitution properties. J. Dairy Sci. 51:331-338.

Pearce, R. J. 1992. Whey Processing. Pages 73-89 in Whey and Lactose Processing. J.G. Zadow, ed. Elsevier Applied Science, New York, NY

Phillip, L. G., D. M. Whitehead, and J. Kinsella. 1994a. Protein stabilized foams. Pages 131-178 in Structure-Function Properties of Food Proteins, Academic Press, San Diego, CA.

Phillip, L. G., D. M. Whitehead, and J. Kinsella. 1994b. Protein stability. Pages 25-63 in Structure-Function Properties of Food Proteins. Academic Press, San Diego, CA.

Phillip, L. G., Z. Haque, and J. E. Kinsella. 1987. A method for the measurement of foam formation and stability. J. Food Sci. 52:1074-1077.
Rankin, S. A., and J. L. Brewer. 1998. Color of nonfat fluid milk as affected by fermentation. J. Food Sci. 63:178-180.

Richard, J. P., and P. Paquin. 1990. Use of a dye binding method for the determination of the protein content of dairy products. Milchwissenschaft 45:92-94.

Ruckold, S., K. H. Grobecker, and H. D. Isengard. 2000. Determination of the contents of water and moisture in milk powder. Fresenius. J. Anal. Chem. 368:522-527.

Russell, C. E., M. E. Matthews, and I. K. Gray. 1980. A comparison of methods for the extraction of the fat from soluble whey protein concentrate powders. N.Z. J. Dairy Sci. Technol. 15:239-244.

Saltmarch, M., and T. P. Labuza. 1980. Influence of relative humidity on the physico-chemical state of lactose in spray dried sweet whey powders. J. Dairy Sci. 45:1231-1236, 1242.

Swaisgood, H. E. 1996. Characteristics of milk. Pages 841-876 in Food Chemistry. 3rd ed. O.R. Fennema, ed. Marcel Dekker, New York, NY

USDA. 2000. U.S. Standards for Dry Whey. Dairy Programs, Agricultural Marketing Service, USDA, Washington, DC.

Ven, C. V. D., H. Gruppen, D. B. A. De Bont, and A. G. H. Voragen. 2002. Correlation between biochemical and foam forming and stabilizing ability of whey and casein hydrolysates. J. Agric. Food Chem. 50:2938-2946.

Woodhams, D. J., and M. J. Murray. 1974. Properties of spray dried milk powders. Neth. Milk Dairy J. 9:172-178.

Yu, M. A., and S. Damodaran. 1991. Kinetics of foam destabilization: Evaluation of a method using bovine serum albumin. J. Agric. Food Chem. 39:1555-1562. 